\title{
Characterization of honeys produced by sympatric species of Afrotropical stingless bees (Hymenoptera, Meliponini)
}

\author{
Hosea O. Mokaya ${ }^{a, *}$, Kiatoko Nkoba ${ }^{a}$, Robert M. Ndunda ${ }^{a}$, Nicolas J. Vereecken ${ }^{\text {b, }}$ \\ ${ }^{a}$ International Centre of Insect Physiology and Ecology (icipe), Nairobi, Kenya \\ ${ }^{\mathrm{b}}$ Agroecology lab, Université libre de Bruxelles (ULB), Brussels, Belgium
}

\section{A R T I C L E I N F O}

\section{Keywords:}

Meliponini

Biochemicals

Antiradical activity

Stingless bees

Phenols

Phytochemicals

\begin{abstract}
A B S T R A C T
We investigated the effect of bee species identity and harvesting methods on the chemical composition and antiradical activity of 53 honey samples, produced by six stingless bee species in western Kenya (Kakamega forest). Our results illustrate that none of the assayed parameters significantly varied between the honey samples harvested by "punching holes" ( $n=25)$ and "squeezing" $(n=28)$ methods. By contrast, species identity drove significant differences in the assayed parameters. Positive correlations between the antiradical activity and the phytochemicals (phenols and flavonoids) were observed, and honeys from Liotrigona sp. exhibited the highest amounts of phenols (214 mg GAE/100 g), flavonoids (73.0 mg QE/100 g) and antiradical activity (76.2\%). The physicochemical analyses confirm the need to establish separate stingless bee honey standards for moisture, free acidity, invertase, electrical conductivity, and HMF, as these parameters significantly diverged from the set limits for Apis mellifera honey.
\end{abstract}

\section{Introduction}

Honey is a complex mixture of mainly sugars and other substances made by honey bees and some related insects from nectar or honeydew (Machado De-Melo, Almeida-Muradian, Sancho, \& Pascual-Maté, 2018). Honey produced by Apis bees is commercialized around the world, and has received considerable attention for its nutritional and health benefits (Rao, Krishnan, Salleh, \& Gan, 2016). Yet, besides Apis mellifera (AM), stingless bees (SB) constitute another, lesser-known group of honey-producing bees within the family Apidae (tribe Meliponini). Unlike AM, which is found on all continents except in Antarctica and in deserts or permafrost regions of the world, SB are essentially found in tropical and subtropical regions, with about 500 species distributed across 32 genera (Grüter, 2020). These bees have distinct features like the presence of a vestigial sting, the capacity to collect nectar or honeydew from flowers of creeping and other small plants, due to their small body size. Furthermore, they have a trend of building broods in a horizontal or vertical position, and a habit to store nectar and pollen in pots rather than combs as in the case of AM (Gonzalez, Amith, \& Stein, 2018; Nkoba, Raina, Muli, Mithöfer, \& Mueke, 2012). Stingless bee colonies can be kept in man-made hives, just like AM - a traditional activity known as meliponiculture (Grüter, 2020; Perichon, Heard, \& Schouten,
2020) - to facilitate the collection of honey, which is used by rural communities in tropical, subtropical and savanna regions of the world as folk medicine, for cultural rituals, as source of both sugars and micronutrients, or for income generation, including in a context of crop pollination (Grüter, 2020; Heard, 1999; Nkoba et al., 2012).

Stingless bee honey (SBH) is steadily gaining acceptance among consumers due to its contrasting and appealing flavor and aroma, a more fluid texture and slow crystallization, all contributing to its high commercial potential (Rao et al., 2016). Another characteristic of this honey is its resistance to form hydroxymethylfurfural (HMF) when subjected to high temperatures (Biluca et al., 2014), which is an added value for its use in pharmaceutical and food industries where the negative effects associated with excess HMF should be avoided (Shapla, Solayman, Alam, Khalil, \& Gan, 2018). A more recent study revealed that SBH is the only natural product known to be enriched with a biologically active sugar (trehalulose), which has both antidiabetic and acariogenic properties (Fletcher et al., 2020). These recent findings among others suggest that current and future research into the chemical properties of SBH, offers opportunities to better characterize these under-investigated natural product (and for some, non-timber forest products), while discovering novel molecules relevant to human.

Investigations into the chemistry and bioactive compounds found in

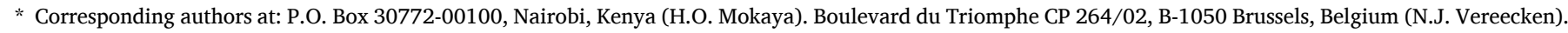

E-mail addresses: hmokaya@icipe.org (H.O. Mokaya), nicolas.vereecken@ulb.be (N.J. Vereecken).
} 
SBH face multiple challenges, among which the characterization of the many potential sources of variation, including the potential for speciesspecific compositional and functional profiles of honeys, the impact of the botanical resources exploited by the foraging bees and their variation in space across their distribution range, as well as the harvesting methods and timing (Leonhardt, Heard, \& Wallace, 2014). Moreover, the sub-Saharan SB (i.e., all species occurring in the area that lies south of the Sahara in Africa) are perhaps the least known of all stingless bees to date, as their taxonomy is still being discussed (Eardley \& Kwapong, 2013), and the study of their honeys is still in its infancy (Nordin, Sainik, Chowdhury, Saim, \& Idrus, 2018).

In this study, we aim to contribute to filling these gaps by investigating the compositional and functional profiles of honeys collected in colonies from a range of different stingless bee species kept in man-made hives around Kakamega forest $\left(0^{\circ} 09^{\prime} \mathrm{N}, 34^{\circ} 50^{\prime} \mathrm{E}\right)$ in western Kenya, a mid-altitude tropical rainforest, UNESCO world heritage Center, and the last remnant of the ancient Guineo-Congolian rainforest (Zimmerman, 1972). Specifically, we investigated (i) the influence of the species on the composition and antiradical activity of honeys stored by six SB species of economic importance (Meliponula togoensis, $M$. ferruginea, $M$. lendliana, $M$. bocandei, Liotrigona sp. and Plebeina armata), among communities around Kakamega forest (Nkoba et al., 2012), and (ii) the extent to which the honey harvesting methods employed by the beekeepers influence the chemical composition and antiradical activity of those honeys. Being the first multi-species survey and analyses of SBH from Kakamega forest, these findings will be an essential prerequisite to the establishment and scaling out of optimal harvesting methods, with the goal of contributing to the definition of species-specific quality standards in SBH across sub-Saharan Africa, as well as to test and document the possible human health benefits of SBH via the quantification of their phytochemicals and their antiradical activity.

\section{Materials and methods}

\subsection{Study location - Kakamega forest (Kenya)}

The surveys were conducted in five meliponaries located in homesteads at Chirobani ( 2 meliponaries), Ivihiga (1 meliponary), Kiborkok (1 meliponary) and Isiekuti (1 meliponary), nearby the indigenous forest portion of Kakamega forest near Kisumu in western Kenya (Latitude: $0^{\circ} 17^{\prime} 18.00^{\prime \prime} \mathrm{N}$; Longitude: $34^{\circ} 51^{\prime} 13.19^{\prime \prime} \mathrm{E}$ ). Chirobani and Ivihiga meliponaries are in the western portion of the forest, while the Kiborkok and Isiekuti meliponaries are in the most southern end of the Kakamega forest.

\subsection{Honey samples}

The dataset consisted of 53 honey samples collected from hives maintained by beekeepers around Kakamega forest in December 2019 (Table 1). Two extraction methods were employed; "punching holes" through the honey pots to allow the honey to drip out $(n=25)$ and "squeezing" the honey out of the honey pots after scrapping them ( $\mathrm{n}=$ 28). All samples were collected in the field, stored in hermetic plastic

Table1

Global Positioning System (GPS) coordinates of sampling sites.

\begin{tabular}{lllll}
\hline Sites & $\begin{array}{l}\text { Number of } \\
\text { meliponaries }\end{array}$ & Latitude & Longitude & $\begin{array}{l}\text { Elevation } \\
\text { (meters) }\end{array}$ \\
\hline Chirobani & 2 & $\mathrm{~N}$ & $\mathrm{E}$ & 1587 \\
& & $00.22193^{\circ}$ & $034.92786^{\circ}$ & \\
Isiekuti & 1 & $\mathrm{~N}$ & $\mathrm{E}$ & 1623 \\
& & $00.15983^{\circ}$ & $034.85622^{\circ}$ & \\
Kiborgok & 1 & $\mathrm{~N} 00$. & $\mathrm{E}$ & 1493 \\
& & $25769^{\circ}$ & $034.75108^{\circ}$ & \\
Ivihiga & 1 & $\mathrm{~N} \mathrm{00.}$ & $\mathrm{E}$ & 1613 \\
& & $28113^{\circ}$ & $034.95480^{\circ}$ & \\
\hline
\end{tabular}

bottles, and then transported in electric cooler box (charged using car charge) at $-18{ }^{\circ} \mathrm{C}$ back to the African Reference Laboratory for Bee Health at the International Centre of Insect Physiology and Ecology (icipe) in Nairobi (Kenya) where they remained stored at $-18{ }^{\circ} \mathrm{C}$ prior to the laboratory analyses described below. All samples were handled the same, right from harvest until analyses.

The honey samples were produced by Liotrigona sp. $(\mathrm{n}=3)$, Meliponula bocandei $(\mathrm{n}=4), M$. ferruginea $(\mathrm{n}=17)$, M. lendliana $(\mathrm{n}=1)$, M. togoensis $(\mathrm{n}=24)$ and Plebeina armata $(\mathrm{n}=4)$ (Fig. 1). These species are characterized by a diverse series of morphological and ecological traits: $M$. bocandei species has a large body size $(7.0 \mathrm{~mm})$ and organizes its brood in clusters, while the $M$. ferruginea and $M$. togoensis specie are smaller than $M$. bocandei but larger in body size $(5.1-5.9 \mathrm{~mm})$ than P. armata (3.3-5.2 mm). On the other, Liotrigona sp. has a body size of between 2.1 and $4.2 \mathrm{~mm}$. M. ferruginea, $M$. togoensis and $P$. armata organize their brood in horizontal combs. In the wild, the $M$. bocandei and $M$. togoensis nest in tree cavities while $P$. armata is an underground cavity nester and its nests are only found in termite mounds. M. ferruginea species nests either in cavities in trees (trunk, branch), underground or in walls of human residential houses (Ndungu et al., 2017; Nkoba et al., 2012).

\subsection{Chemicals and reagents}

Chemicals and solvents were of analytical or HPLC grade. HMF standard, Folin-Ciocalteu's phenol reagent, 2,2-diphenyl-1-picrylhydrazyl (DPPH), water, methanol, potassium hydrogen phosphate, disodium hydrogen phosphate, p-nitrophenyl- $\alpha$-D-glucopyranoside, trishydroxymethyl amino methane, proline standard, formic acid (99\%), ninhydrin, ethylene glycol monomethyl ether, 2-propanol, $0.45 \mu \mathrm{m}$ nylon filters, $\mathrm{NaNO}_{2}, \mathrm{AlCl}_{3}, \mathrm{NaOH}$, quercetin, sodium carbonate, and gallic acid, were supplied by Sigma-Aldrich Co. (Kobian, Kenya).

\subsection{Instrumentation}

We used pH and conductivity meters (Jenway 3540, Essex, England), a handheld digital refractometer (Atago, Tokyo, Japan), a water activity meter (WA - 60A, Guangzhou Landtek Instruments, China), a UV/Vis spectrophotometer (Jenway 6850, Kobian, Kenya), and a high performance liquid chromatography (HPLC) (1260 series, Agilent Technologies, Santa Clara, CA, USA).

\subsection{Physicochemical analyses}

Physiochemical parameters were determined as per the International Honey Commission (IHC, 2009) except for the Water activity $\left(a_{w}\right)$ and sugars in ${ }^{\circ}$ Brix, which were determined as per (Yap, Chin, Yusof, \& Chong, 2019) and AOAC (2005), respectively.

\subsection{1. $p H$ and free acidity}

A pH and conductivity meter was used to measure the $\mathrm{pH}$ of $10 \mathrm{~g}$ of honey in $75 \mathrm{ml}$ of carbon dioxide free distilled water. Free acidity was done by titrating the same sample solution with $0.1 \mathrm{M} \mathrm{NaOH}$ until a pH 8.3 was attained.

\subsubsection{Moisture content}

The moisture content was determined using a refractometric method. The refractive indices of honey samples were measured at room ( 20 to $25^{\circ} \mathrm{C}$ ) temperature using a handheld digital refractometer and the corresponding moisture contents (\%) were recorded.

\subsubsection{Water activity $\left(a_{w}\right)$}

This was determined at $25{ }^{\circ} \mathrm{C}$ by means of a water activity meter as previously described (Yap et al., 2019). 

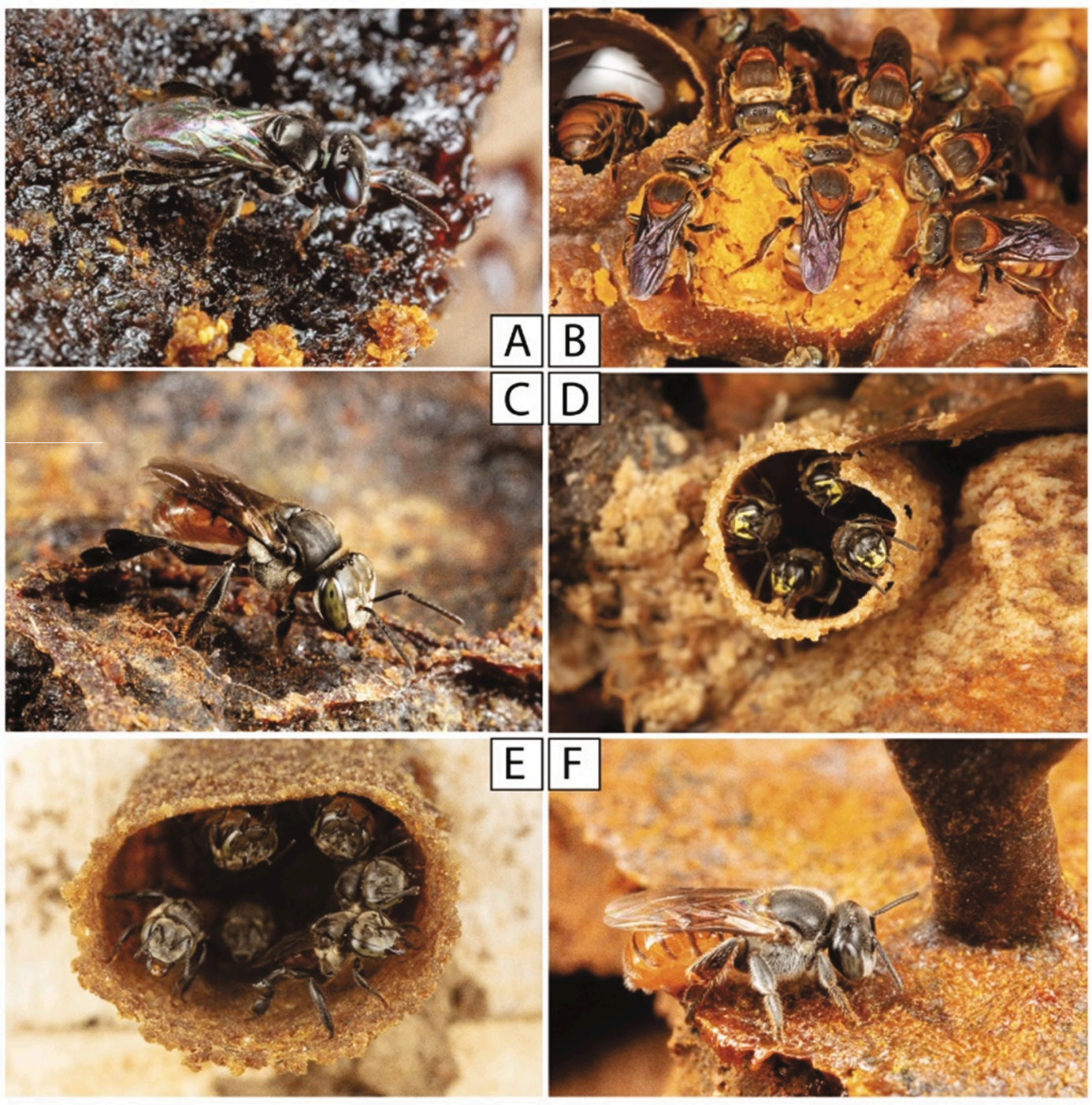

Fig. 1. Sympatric Afrotropical species investigated in this study. A. Liotrigona sp. worker at nest entrance; B. Workers of Meliponula (Meliponula) bocandei inside their nest; C. Worker of Meliponula (Axestotrigona) ferruginea inside its nest; D. Workers of Meliponula (Meliplebeia) lendliana at nest entrance; E. Workers of Meliponula (Axestotrigona) togoensis at nest entrance; F. Plebeina armata worker inside a its nest hosted in an underground termite colony. All photographs by NJ Vereecken.

\subsubsection{Electrical conductivity}

Electrical conductivity was measured using a $\mathrm{pH}$ and conductivity meter for a $20 \%(\mathrm{w} / \mathrm{v})$ solution of honey suspended in distilled water. The meter was calibrated with conductivity solution before taking the readings of honey solutions and conductance was given in $\mathrm{mS} / \mathrm{cm}$.

$\mathrm{S}_{\mathrm{H}}=\mathrm{K}^{*} \mathrm{G}$

where;

$\mathrm{S}_{\mathrm{H}}=$ electrical conductivity of the honey solution in $\mathrm{mS} / \mathrm{cm}$

$\mathrm{K}=$ cell constant in $\mathrm{cm}^{-1}(0.93)$

$\mathrm{G}=$ conductance in $\mathrm{mS}$

\subsubsection{Invertase activity}

This was determined spectrophotometrically. Five grams of the sample were dissolved in $25 \mathrm{ml}$ buffer solution (11.66 $\mathrm{g}$ of potassium hydrogen phosphate, and $2.56 \mathrm{~g}$ of disodium hydrogen phosphate in $1 \mathrm{~L}$ of water), to make honey solution. Then, five $\mathrm{ml}$ of the substrate solution (6.03 $\mathrm{g}$ of p-nitrophenyl- $\alpha$-D- glucopyranoside in $1 \mathrm{~L}$ of buffer solution) was transferred into two separate test tubes and incubated in a water bath for $5 \mathrm{~min}$ at $40^{\circ} \mathrm{C}$. After incubation, $0.5 \mathrm{ml}$ of the honey solution was added to one test tube (sample) and $0.5 \mathrm{ml}$ of reaction terminating solution ( $363.4 \mathrm{~g}$ of tris- hydroxymethyl amino methane in 11 of water) to the other test tube (blank). The test tubes were further incubated for $20 \mathrm{~min}$ after which $0.5 \mathrm{ml}$ of reaction terminating solution was added to the sample and $0.5 \mathrm{ml}$ of honey solution to the blank. The absorbance of the sample against the blank was measured after $15 \mathrm{~min}$ at $400 \mathrm{~nm}$ using a UV/Vis spectrophotometer.

Invertase in invertase number $(\mathrm{IN})=21.64 * \mathrm{~A}_{400} \mathrm{~nm}$

Where: 21.64 is the slope

\subsubsection{Proline content}

The spectrophotometric method was used as follows; $0.5 \mathrm{ml}$ of the honey solution ( $5 \% \mathrm{w} / \mathrm{v}$ ) was placed in one tube, $0.5 \mathrm{ml}$ of water (blank) into a second tube and $0.5 \mathrm{ml}$ of proline standard solution into two other tubes. To these tubes, $1 \mathrm{ml}$ of formic acid (99\%) and $1 \mathrm{ml}$ of ninhydrin solution ( $3 \% \mathrm{w} / \mathrm{v}$ in ethylene glycol monomethyl ether) was added. The tubes were capped and stirred for $15 \mathrm{~min}$ and then transferred into a boiling water bath $\left(100{ }^{\circ} \mathrm{C}\right)$ for $15 \mathrm{~min}$. After $15 \mathrm{~min}$, the tubes were moved to a water bath at $70^{\circ} \mathrm{C}$ for $10 \mathrm{~min}$. Finally, $5 \mathrm{ml}$ of the propanolwater solution (1:1) was added to each tube, capped immediately then left to cool before the absorbances were measured $45 \mathrm{~min}$ later at 510 $\mathrm{nm}$. Proline content was calculated as follows; 
Proline content $(\mathrm{mg} / \mathrm{kg})=\mathrm{Es} / \mathrm{Ea} * \mathrm{E} 1 / \mathrm{E} 2 * 80$

where;

Es $=$ Absorbance of the sample solution

$\mathrm{Ea}=$ Absorbance of the proline standard solution (average of two readings),

$\mathrm{E} 1=\mathrm{mg}$ proline taken for the proline solution preparation

$\mathrm{E} 2=$ Weight of honey in $\mathrm{g}$.

$80=$ Dilution factor

\subsubsection{Hydroxymethylfurfural (HMF)}

The HMF was determined using high performance liquid chromatography (HPLC) equipped with a diode array detector (DAD, G1315D), a binary pump and an auto sampler, all from Agilent. Separation was on an Agilent C18, $4.6 \times 100 \mathrm{~mm}, 3.5 \mu \mathrm{m}$ column. Briefly, honey samples $(10 \mathrm{~g})$ were diluted to $50 \mathrm{ml}$ with distilled water, filtered using a $0.45 \mu \mathrm{m}$ nylon filter and injected $(10 \mu \mathrm{l})$ into an HPLC system. The HPLC method included an isocratic mobile phase of $85 \%$ water and $15 \%$ methanol with a flow rate of $1.0 \mathrm{ml} / \mathrm{min}$ at $30{ }^{\circ} \mathrm{C}$. The detection wavelength was $285 \mathrm{~nm}$. HMF concentration in the samples was calculated by comparing the corresponding peak areas of the samples and HMF standard (1 - 10 ppm) curve after correcting for the dilution of the samples. HMF was expressed in $\mathrm{mg} / \mathrm{kg}$ honey.

\subsubsection{Sugars $\left({ }^{\circ}\right.$ Brix)}

The total sugars (soluble solids) were determined according to AOAC (2005), by recording a reading of the honey sample in a handheld digital refractometer.

\subsection{Phytochemical contents analyses}

\subsubsection{Total flavonoids content (TFC)}

They were determined using the method of Dowd as in published procedures (Mokaya, Bargul, Irungu, \& Lattorff, 2020). Briefly, $1 \mathrm{ml}$ extract of the sample ( $1 \mathrm{~g}$ of honey in $4 \mathrm{ml}$ of water) was mixed with $4 \mathrm{ml}$ of distilled water, then $300 \mu \mathrm{l}$ of $5 \% \mathrm{NaNO}_{2}$ was added and mixed. After $5 \mathrm{~min}, 300 \mu \mathrm{l}$ of $10 \% \mathrm{AlCl}_{3}$ was added and left for $1 \mathrm{~min}$ before adding 2 $\mathrm{ml}$ of $1 \mathrm{M} \mathrm{NaOH}$ and $2.4 \mathrm{ml}$ of distilled water. The absorbance was measured against the blank (the mixture minus the sample) at $510 \mathrm{~nm}$. Quercetin (Q) was used to generate a calibration curve $(20-200 \mu \mathrm{g} / \mathrm{ml})$, and TFC were expressed as $\mathrm{mg} Q$ equivalent (E)/100 $\mathrm{g}$ honey.

\subsubsection{Total phenols content (TPC)}

They were quantified following the Folin-Ciocalteu method as described in published protocols (Mokaya et al., 2020). One gram of honey was diluted with $20 \mathrm{ml}$ of distilled water. To $1 \mathrm{ml}$ of the honey solution in a test tube, $5 \mathrm{ml}$ of $0.2 \mathrm{~N}$ Folin-Ciocalteu reagent was added. After $5 \mathrm{~min}, 4 \mathrm{ml}$ of $75 \mathrm{~g} / 1$ sodium carbonate was added before the mixture was incubated at room temperature $\left(20\right.$ to $\left.25{ }^{\circ} \mathrm{C}\right)$ for $2 \mathrm{~h}$. The absorbance was read at $760 \mathrm{~nm}$ against a water blank. Gallic acid (GA) standard was used to yield a calibration curve $(0-250 \mu \mathrm{g} / \mathrm{ml})$. The TPC was expressed as $\mathrm{mg}$ of GAE/100 $\mathrm{g}$ honey.

\subsection{Analysis of radical scavenging activity (RSA)}

\subsubsection{DPPH radical scavenging activity}

The spectrophotometric method as previously reported was used with minor modifications (Mokaya et al., 2020). To $0.75 \mathrm{ml}$ methanolic honey solution ( $50 \mathrm{mg} / \mathrm{ml}$ ), $1.5 \mathrm{ml}$ of $20 \mathrm{mg} / \mathrm{l} \mathrm{DPPH}$ solution ( $2 \mathrm{mg}$ of DPPH in $100 \mathrm{ml}$ of methanol) was added and the mixture was incubated for $15 \mathrm{~min}$ at room temperature in the dark. The absorbance was measured at $517 \mathrm{~nm}$ against a blank sample $(0.75 \mathrm{ml}$ honey solution with $1.5 \mathrm{ml}$ methanol). The control sample consisted of $0.75 \mathrm{ml}$ methanol mixed with $1.5 \mathrm{ml}$ DPPH solution, with methanol as its blank. The antiradical activity was expressed as a percentage inhibition, relative to the control sample.

Radical scavenging activity (RSA) expressed as $\%$ inhibition $=[$ (control absorbance - sample absorbance)/control absorbance] * $100 \%$

\subsection{Statistical analyses}

\subsubsection{Analysis of honey similarity - Impact of species and harvesting methods.}

All the assayed parameters were done in triplicate. We used the vegan package (version 2.0-5) in RStudio (version 1.1.456) (RStudio Team, 2016) for $R$ ( $R$ Core Team, 2018) to perform a multivariate analysis of similarities (ANOSIM) using the average Bray-Curtis distances among samples to test statistically whether there was a significant difference in honey composition between species, and the harvesting methods. Non-linear multidimensional scaling (NMDS) plot was used to highlight the effects induced by the bee species and harvesting methods on honey composition and its antiradical activity. The NMDS was computed using the function "metaMDS" of the "vegan" package in RStudio (version 1.1.456) (RStudio Team, 2016) for R (R Core Team, 2018). Box plots were done using $R$ v3.6.2 ( $R$ Core Team, 2018), the factoextra (v1.0.6, Kassambara \& Mundt, 2019) and ggplot2 v3.2.1 (Wickham, Chang, \& Wickham, 2016) packages, to show variation of phytochemicals between the species irrespective of the harvesting methods. Kruskal-Wallis test was used to check for species-specific patterns in each assayed parameter, as nine of the twelve parameters failed the Shapiro's test for normality $(\mathrm{p}>0.05)$.

\subsubsection{Pairwise comparisons of honey parameters}

The pairwise comparisons of stingless bee honey parameters described above were visualized with the ggpairs function in the GGally package (version version 1.4.0.) (Schloerke et al., 2018) in RStudio (version 1.1.456) (RStudio Team, 2016) for R (R Core Team, 2018); a loess regression was fitted to the observed data with $95 \%$ confidence band intervals around the fit. The scatter plot produced also allows the computation of Pearson's correlation coefficient for each pair of variables, both irrespective of the species and harvesting methods (i.e., "punching holes" vs. "squeezing").

\section{Results and discussion}

\subsection{Harvesting methods and bee species in relation to honey properties}

The ANOSIM analyses showed no significant impact of the harvesting methods on the stingless bee honey composition and antiradical activity (R-stat $=0.0069, \mathrm{p}=0.3223$ ), but a significant effect of the target species on the same properties (R-stat $=0.274, \mathrm{p}<0.001$ ). These similarities and differences are summarized in the NMDS plot (Fig. 2). This agreed with the Kruskal-Wallis test results for species-specific patterns in each of the assayed parameter (Table 1 and Fig. 2), which showed that $66.7 \%$ of the parameters varied significantly among the studied species. Stress value for the two- dimensional plot was equal to 0.174 and non-metric goodness-of-fit measured with the Shepard's diagram was $r^{2}=0.970$, allowing a safe interpretation of the data. Convex hulls comprising samples associated to each honey harvesting method were overlapping to a considerable extent, indicating no impact of the harvesting method on the honey properties (Fig. 2a), a result consistent with the ANOSIM analysis above. By contrast, as shown in Fig. $2 \mathrm{~b}$ of the NMDS analyses, a series of samples associated to different stingless bee species appeared more clearly separated into discrete clusters. This is particularly the case for samples associated to bees in the genera Liotrigona and Plebeina which appeared to cluster further outside the otherwise overlapping convex hulls comprising samples scattered over a large area of the phenotypic space, and associated to the remaining four 

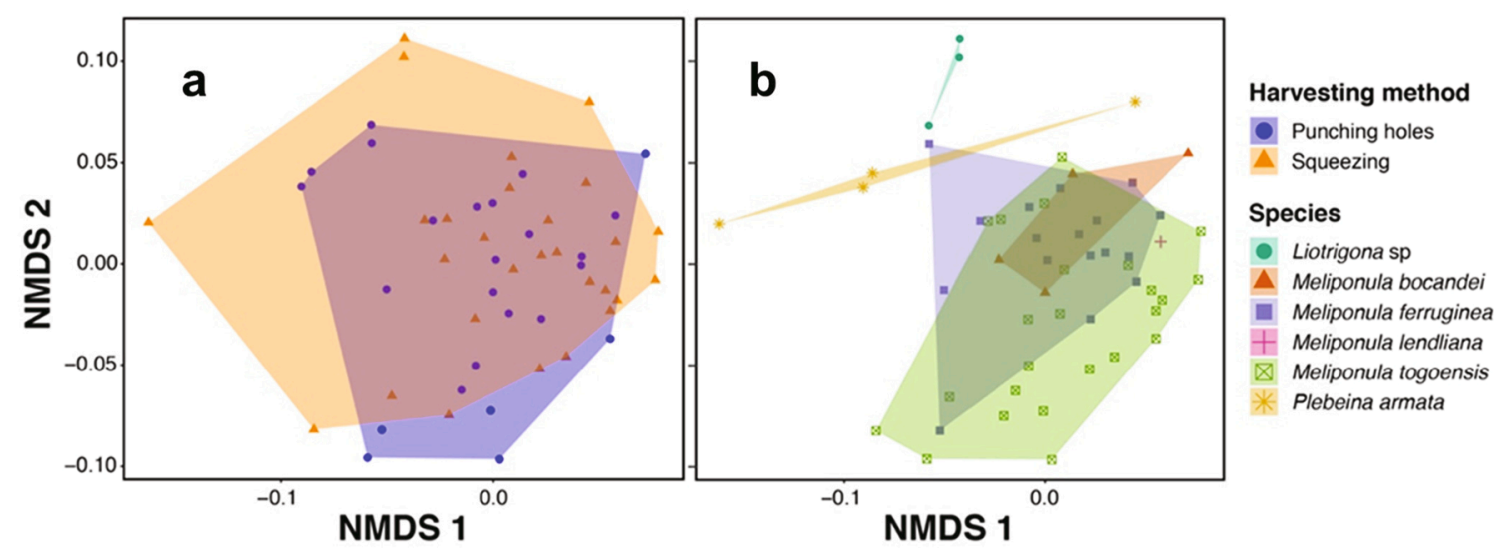

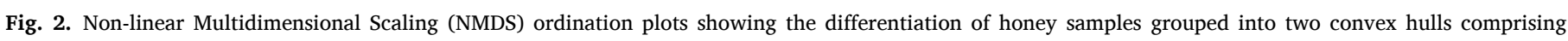

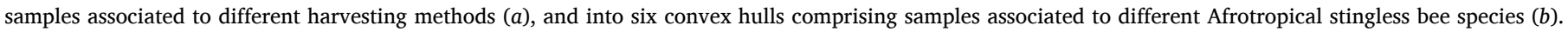

species in the genus Meliponula (Fig. 2b).

However, the "punching holes" method is encouraged as it results in clean honey, thus minimizing subsequent processing steps, i.e., it eliminates the need for filtration. Furthermore, this method allows for a faster repair of the honey pots by the bees compared to scrapping and squeezing pots, which destroys the pots completely. Any method (harvesting or processing) that negatively affects the honey chemical composition, particularly the physicochemical properties, lowers the quality of that honey (Hempattarasuwan, Settachaimongkon, \& Duangmal, 2019).

We hypothesize that the species-specific honey profiles illustrated by the clustering of samples according to the bee species are largely associated to the fact that different co-occurring stingless bee species might exploit slightly different ecological niches and host plants for the collection of honeydew and nectar (Shamsudin et al., 2019). Therefore, characterizing the foraging patterns of African stingless bees as part of their ecological and climatic niche, and the identification of their host plants from mixed-species pollen loads, will undoubtedly be of significance for future research.

Further, our results agree with the findings of a previous study that illustrated how ten different stingless bee species in Brazil, produce honey of varying composition (Biluca, Braghini, Gonzaga, Costa, \& Fett, 2016). Similar results were also reported by Espinoza-Toledo and colleagues, where they observed clustering of honey samples according to the species identity (Melipona solani, M. beecheii, and Scaptotrigona mexicana), in the same region (Espinoza Toledo et al., 2018).

\subsection{Physicochemical properties}

The results for physicochemical properties are presented in Table 2 as the mean \pm standard deviation.

\subsubsection{Water activity $\left(a_{w}\right)$ and moisture content}

Water activity depict the available water for microbial growth in foods, and 0.6 is the minimum $\mathrm{a}_{\mathrm{w}}$ for the osmophilic yeast to thrive and cause unwanted fermentation. The $\mathrm{a}_{\mathrm{w}}$ ranged from 0.70 to 0.77 , where the highest values were from $M$. lendliana and the lowest values were from $M$. bocandei and $M$. ferruginea samples. These results corroborated with those reported for Kelulut honey (0.79) (Yap et al., 2019), and Trigona carbonaria honey (0.74) (Oddo et al., 2008). Despite its high $\mathrm{a}_{\mathrm{w}}$ content, $\mathrm{SBH}$ is relatively resistant to fermentation due to its low $\mathrm{pH}$ and high free acidity, which deters the growth of microbes.

High moisture could favor unwanted honey fermentation during storage caused by osmophilic yeast, thus a useful quality control criterion (Nordin et al., 2018). Samples from all the species had higher moisture values than the recommended limit $(\leq 20 \%)$ for AMH (Codex Alimentarius Commission, 2001). The values varied between 26.1 and $35.9 \%$. Of the studied species, $M$. lendliana sample reached the highest while $M$. ferriginea samples had the least amount of moisture. A similar range of values have been cited for stingless bee honey in the past studies, e.g., a range of $23.1-43.5 \%$ was recorded for honey samples from ten species of Brazil (Biluca et al., 2016), and $25.0-47.0 \%$ for Thailand samples (Chuttong, Chanbang, Sringarm, \& Burgett, 2016). Also, a range of 25.1 - 35.0 \% was recorded for Ethiopian Meliponula

Table 2

Influence of stingless bee species on the physicochemical properties of stingless bee honey (mean $\pm \mathrm{SD}$ ).

\begin{tabular}{|c|c|c|c|c|c|c|c|c|c|c|}
\hline Species & $\mathrm{n}$ & $\begin{array}{l}\text { Water } \\
\text { activity }\left(\mathrm{a}_{\mathrm{w}}\right)\end{array}$ & $\begin{array}{l}\text { Moisture } \\
(\%)\end{array}$ & $\mathrm{pH}$ & $\begin{array}{l}\text { Free acidity } \\
(\mathrm{meq} / \mathrm{kg})\end{array}$ & $\begin{array}{l}\text { Electrical conductivity } \\
(\mathrm{mS} / \mathrm{cm})\end{array}$ & $\begin{array}{l}\text { Proline } \\
(\mathrm{mg} / \mathrm{kg})\end{array}$ & $\begin{array}{l}\text { Invertase } \\
\text { activity (IN) }\end{array}$ & $\begin{array}{l}\mathrm{HMF} \\
(\mathrm{mg} / \mathrm{kg})\end{array}$ & $\begin{array}{l}\text { Sugars }(\% \\
\text { Brix) }\end{array}$ \\
\hline Liotrigona sp. & 3 & $0.73 \pm 0.02$ & $29.1 \pm 1.4$ & $\begin{array}{l}4.0 \pm \\
0.1\end{array}$ & $270 \pm 38$ & $1.6 \pm 0.3$ & $771 \pm 142$ & $8.9 \pm 1.1$ & $\begin{array}{l}11.6 \pm \\
18.0\end{array}$ & $71.0 \pm 1.4$ \\
\hline $\begin{array}{r}\text { Meliponula } \\
\text { bocandei }\end{array}$ & 4 & $0.70 \pm 0.02$ & $27.6 \pm 6.3$ & $\begin{array}{l}4.4 \pm \\
0.5\end{array}$ & $48 \pm 24$ & $0.6 \pm 0.1$ & $457 \pm 125$ & $2.8 \pm 2.3$ & $\begin{array}{l}11.2 \pm \\
11.7\end{array}$ & $72.4 \pm 6.3$ \\
\hline $\begin{array}{r}\text { Meliponula } \\
\text { ferriginea }\end{array}$ & 17 & $0.70 \pm 0.03$ & $26.1 \pm 2.6$ & $\begin{array}{l}4.9 \pm \\
0.4\end{array}$ & $38 \pm 26$ & $1.0 \pm 0.2$ & $443 \pm 99$ & $3.7 \pm 1.9$ & $\begin{array}{l}10.6 \pm \\
10.4\end{array}$ & $73.9 \pm 2.6$ \\
\hline $\begin{array}{r}\text { Meliponula } \\
\text { lendliana }\end{array}$ & 1 & 0.77 & 35.9 & 4.5 & 52 & 1.2 & 491 & 1.1 & 13.4 & 64.1 \\
\hline $\begin{array}{r}\text { Meliponula } \\
\text { togoensis }\end{array}$ & 24 & $0.74 \pm 0.03$ & $31.2 \pm 3.2$ & $\begin{array}{l}5.0 \pm \\
0.5\end{array}$ & $30 \pm 14$ & $1.1 \pm 0.1$ & $379 \pm 188$ & $4.5 \pm 4.0$ & $\begin{array}{l}15.8 \pm \\
10.0\end{array}$ & $68.8 \pm 3.2$ \\
\hline Plebeina armata & 4 & $0.71 \pm 0.03$ & $27.2 \pm 2.7$ & $\begin{array}{l}4.0 \pm \\
0.3\end{array}$ & $141 \pm 63$ & $0.6 \pm 0.1$ & $415 \pm 204$ & $4.6 \pm 2.9$ & $\begin{array}{l}55.2 \pm \\
45.4\end{array}$ & $72.9 \pm 2.7$ \\
\hline Chi-squared & & 18.5 & 21.9 & 20.8 & 20.6 & 25.5 & 10.6 & 9.22 & 7.25 & 21.9 \\
\hline df & & 5 & 5 & 5 & 5 & 5 & 5 & 5 & 5 & 5 \\
\hline p-value & & $\leq 0.05$ & $<0.001$ & $<0.001$ & $<0.001$ & $<0.001$ & $>0.05$ & $>0.05$ & $>0.05$ & $<0.001$ \\
\hline
\end{tabular}

The analyses were done following Kruskal-Wallis test for $\mathrm{p} \leq 0.05 . \mathrm{n}=$ number of samples, $\mathrm{df}=$ degree of freedom, and IN $=$ invertase number, $\mathrm{SD}=$ standard deviation. 
beccarii honey samples (Gela, Hora, Kebebe, \& Gebresilassie, 2021). The two parameters ( $\mathrm{a}_{\mathrm{w}}$ and moisture) had a strong positive correlation $\left(\mathrm{r}^{2}\right.$ $=0.703$, Fig. 3). Environmental factors during harvesting are among the key determinants of honey's moisture content. The high moisture content in SBH may therefore be due to the nature of their habitat i.e., the humid tropical and subtropical regions (Nordin et al., 2018).

\subsection{2. $p H$ and free acidity}

All the samples were acidic in nature, having $\mathrm{pH}$ values between 4.0 and 5.0. The lowest values (most acidic) were found in Liotrigona sp. and $P$. armata samples, while the highest values (less acidic) were found in $M$. togoensis samples. Stingless bee honeys from Brazil had a $\mathrm{pH}$ range of 3.3 - 6.6, and 3.1 - 3.9 (Biluca et al., 2016; Sousa et al., 2016), and Thailand SBH samples were found to have a $\mathrm{pH}$ range of 3.1- 5.3 (Chuttong et al., 2016). A study on Scaptotrigona pectoralis honey (Moguel, Sosa-Moguel, Pino, Bolivar-Moreno, \& Cuevas-Glory, 2019), also recorded a low pH value (3.6). The low pH of honey is of significance as it inhibits the growth of microbes, hence maintaining the stability, and the shelf life of honey (Lage et al., 2012).

Free acidity varied between 30 and $270 \mathrm{meq} / \mathrm{kg}$, with Liotrigona sp. and $P$. armata exhibiting extraordinarily high free acidity values of 270 and $141 \mathrm{meq} / \mathrm{kg}$, respectively. Samples from three of the studied species had values within the recommended limit for AMH $(\leq 50 \mathrm{meq} / \mathrm{kg}$ ) (Codex Alimentarius Commission, 2001). Our results were in agreement with what was observed by Nordin and coworkers (Nordin et al., 2018), where $59.6 \%$ out of the 472 stingless bee honey samples, had their free acidity values within the set standard for AMH. Previous studies have reported a similar range of values for SBH (Biluca et al., 2016; Moguel et al., 2019). Honey acidity derives from the organic acids, particularly the gluconic acid, which vary among samples based on floral composition, the bee species, and the rate of fermentation of sugars to alcohol, and further oxidation to carboxylic acids (Lage et al., 2012; Sousa et al., 2016). A strong negative correlation $\left(r^{2}=-0.605\right.$, Fig. 3$)$ between the
$\mathrm{pH}$ and free acidity was recorded, implying that the lower the $\mathrm{pH}$, the higher the free acidity, and vice vasa. Just like the low $\mathrm{pH}$, the high free acidity in honey is crucial as it deters microbial development (Lage et al., 2012).

\subsubsection{Electrical conductivity}

Honey's conductivity is due to the presence of minerals, proteins, organic acids, and other organic compounds (Nordin et al., 2018). There was variability among the studied species as the values ranged from 0.6 to $1.6 \mathrm{mS} / \mathrm{cm}$. The lowest values were found in $P$. armata and $M$. bocandei samples, while the highest values were recorded in Liotrigona sp samples. Consistent with these values are those found by (Biluca et al., 2016) for Brazilian SBH samples $(0.15-1.34 \mathrm{mS} / \mathrm{cm})$ and (Chuttong et al., 2016) for Thailand SBH samples $(0.32-3.10 \mathrm{mS} / \mathrm{cm})$. Contrary, the samples from $M$. subnida and $M$. scutellaris, which showed comparatively low values that ranged from 0.30 to $0.67 \mathrm{mS} / \mathrm{cm}$ (Sousa et al., 2016). It is used alongside other parameters like palynological assay to determine honey floral origin. Strong positive correlations were recorded between the electrical conductivity and the phytochemicals, which are organic compounds $\left(\mathrm{r}^{2}=0.590\right.$ with TFC, and $\mathrm{r}^{2}=0.592$ with $\mathrm{TPC}$, respectively). When compared to the set limit for $\mathrm{AMH}(\leq 0.8 \mathrm{mS}$ / $\mathrm{cm}$ ), four of the studied species had high values (Commission, 2001).

\subsubsection{Proline}

Liotrigona sp. honeys had higher proline $(771 \mathrm{mg} / \mathrm{kg}$ ) than other species while $M$. togoensis honeys had the least amount $(379 \mathrm{mg} / \mathrm{kg}$ ). A study on Ethiopian Meliponula beccarii honey samples reported a comparable proline content mean of $214.5 \mathrm{mg} / \mathrm{kg}$ (Gela et al., 2021). However, a study by Sousa et al. (2016) found low proline values. Proline is one of the major free amino acids found in a abundance in honey, and is assayed as an indicator of honey maturity and to check for adulteration (Sousa et al., 2016). Since proline is also related to the floral source and the amount of pollen present in the honey it could be

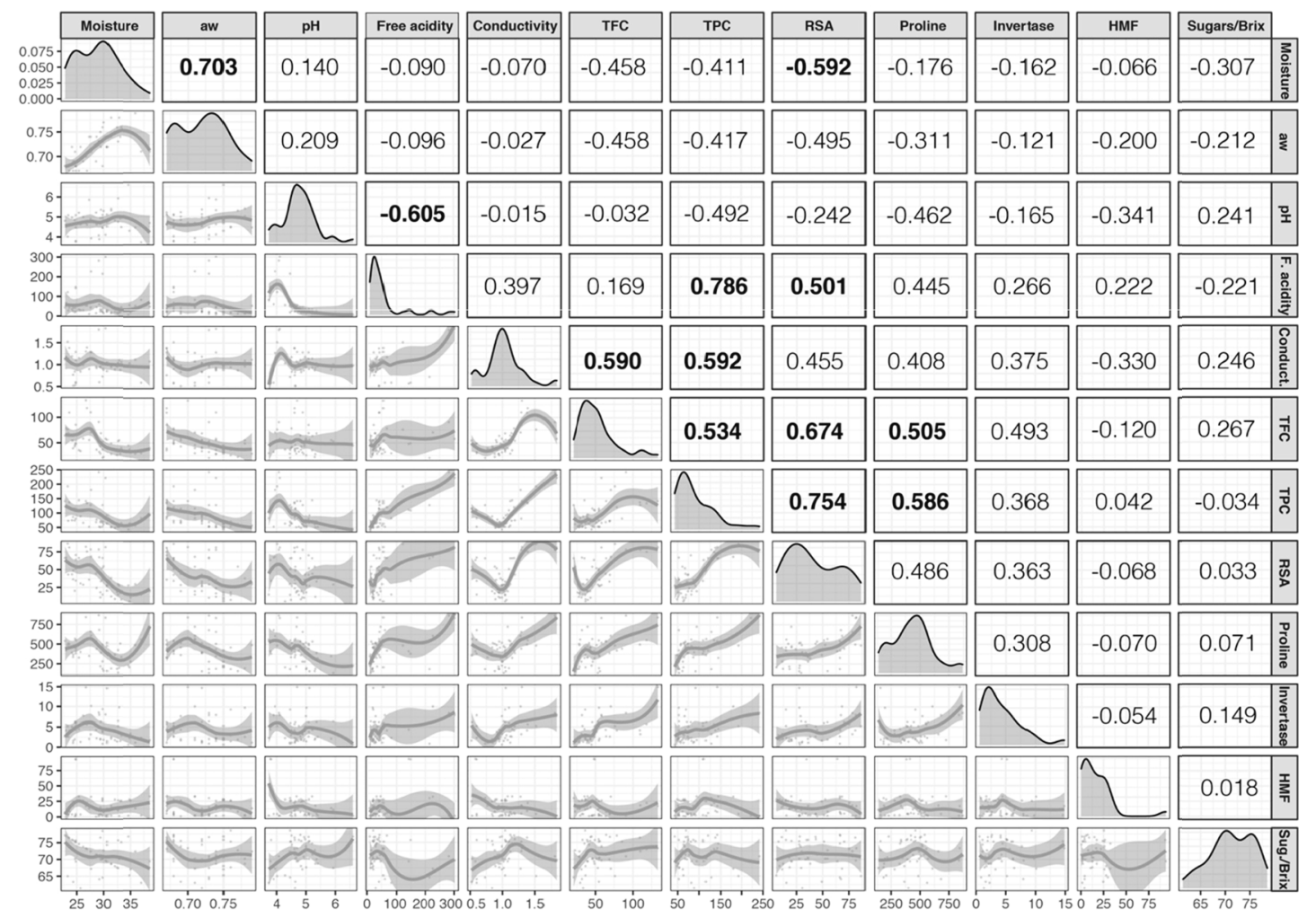

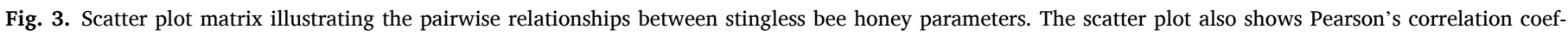

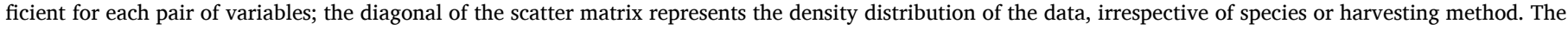
results indicate that most variables are weakly correlated (values in bold indicate Pearson's correlation coefficient $> \pm 0.5$ ). 
useful for the characterization of the botanical sources of honey. As per the Codex Alimentarius Commission (2001), the proline limit for AMH should be $\geq 180 \mathrm{mg} / \mathrm{kg}$, and all the studied stingless bees honey samples met this limit.

\subsubsection{Invertase activity}

The lowest values were observed in M. lendliana (1.1 IN), while the largest values were found in Liotrigona sp honeys (8.9 IN). Three of the studied species had values above the minimum limit ( $\geq 4$ IN) for AMH (Codex Alimentarius Commission, 2001). Previous studies have reported comparable values for invertase activity in SBH, e.g., in Malaysian SBH, the range was between 0.27 and 4.94 IN (Julika et al., 2020), and an average of 22.0 IN for $S$. pectoralis honey (Moguel et al., 2019).

Invertase is used as indicator of honey freshness or prolonged storage, due to its high sensitivity to heat and tendence to deteriorate over time. The detected low enzyme activity for some of the studied samples, which were freshly obtained from the honey pots, may be regarded as a natural feature for $\mathrm{SBH}$, rather than an index of scarce freshness or prolonged storage. Therefore, the use of enzyme activity as an indicator of freshness, as is commonly used for AMH, may not be applicable for SBH (Nordin et al., 2018).

\subsubsection{Hydroxymethylfurfural (HMF)}

HMF is an important honey quality parameter, widely used as an indicator of honey freshness and adulteration from external sources (Sousa et al., 2016). HMF is generally absent in freshly harvested honey, but it tends to surge over time. It is formed by the reaction of sugars, particularly fructose, with the acids. The range for HMF was from 10.6 to $55.2 \mathrm{mg} / \mathrm{kg}$ and the highest values were measured in the samples of $P$. armata while the lowest values were in $M$. ferruginea samples. Most of the studied species (5), showed HMF values within the range established by the Codex Alimentarius Commission (2001) of $\leq 40 \mathrm{mg} / \mathrm{kg}$ for AMH. A study by Holanda et al. (2012) revealed that HMF of $M$. fasciculata honey varied between 5.44 and $70.79 \mathrm{mg} / \mathrm{kg}$. Equally, a range of $28.0-$ $58.3 \mathrm{mg} / \mathrm{kg}$ was reported for Brazilian SBH (Nascimento et al., 2015). Normally, under proper storage conditions, and low temperatures it forms slowly, but when honey is exposed to high temperatures, poor storage conditions, or addition of boiled sucrose, the HMF rises (Shapla et al., 2018).

\subsubsection{Sugars $\left({ }^{\circ}\right.$ Brix $)$}

The sugars, especially reducing sugars, influence the energy value of honey, thus they are an immediate source of energy for bees (Sousa et al., 2016). The sugars ranged from 64.1 (M. lendliana sample) to $73.9^{\circ}$ Brix (M. ferruginea samples). A similar range $\left(55.2-76.1^{\circ}\right.$ Brix) was recorded by (Biluca et al., 2016) for SBH samples from Brazil. Compared to $\mathrm{AMH}$, the values for $\mathrm{SBH}$ are low due to their high water content and low sugars. For instance, Nordin and colleagues (Nordin et al., 2018)
A
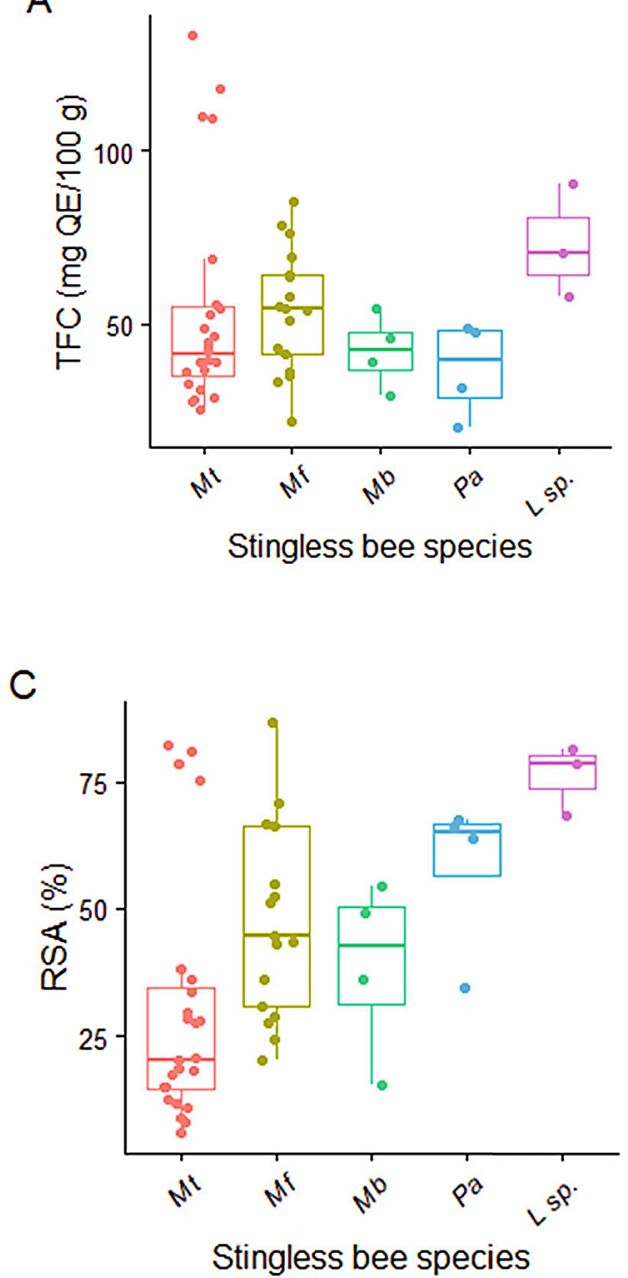

B

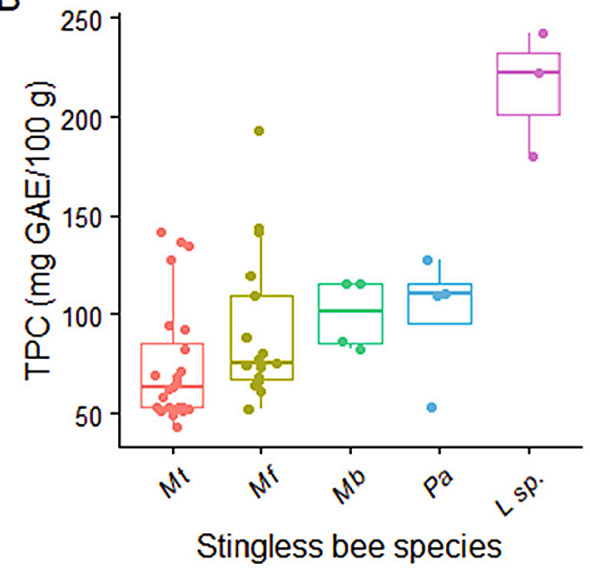

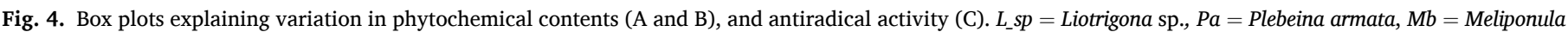

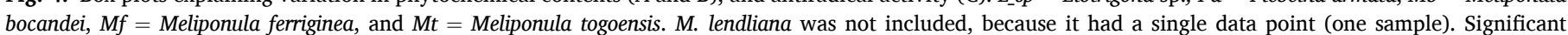

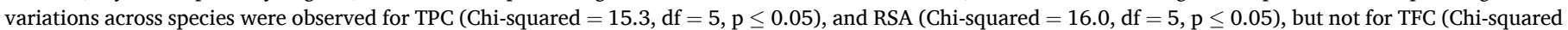
$=9.21$, df $=5, \mathrm{p}>0.05)$. 
noticed a range of 64.5 to $75.8^{\circ} \mathrm{Brix}$ in SBH compared to a range of 78.77 to $316.92^{\circ} \mathrm{Brix}$ in $\mathrm{AMH}$, in the papers they reviewed. More sugars in honey results in a high osmotic pressure, which discourages development of microbes, thus favoring longer shelf life of honey.

The physicochemical data support the need to establish separate quality standards for SBH, to avoid unfair rejection of otherwise good honey, agreeing with other researchers who have voiced similar concerns (Chuttong et al., 2016; Nordin et al., 2018).

\subsection{Phytochemicals}

These results are shown in Fig. 4. The TPC ranged from 57 to $214 \mathrm{mg}$ GAE/100 g, with $M$. lendliana sample recording the least amount while Liotrigona sp. honeys recording the highest amount (Fig. 4, A). Previous studies on SBH recorded comparable values, e.g., scales of $10.3-98.0$ mg GAE/100 g (Biluca et al., 2016) and 31.5 - 126.6 mg GAE/100 g (Sousa et al., 2016) were recorded for honeys from different stingless bee species. Similarly, a study on AMH samples from Kenya found a comparable range of values (Mokaya et al., 2020).

The TFC ranged from 28.7 to $73.0 \mathrm{mg} \mathrm{QE} / 100 \mathrm{~g}$ (Fig. 1, B). Honeys from Liotrigona sp. showed the highest $\mathrm{TFC}$, and samples from $M$. lendliana demonstrated the lowest TFC. The TFC values for the current study are higher than those previously cited for this type of honey (Sousa et al., 2016), and this could be due the differences in floral composition in different geographic regions and the different producing species. Compared to AMH from Kenya, a significant difference ( $\mathrm{p}<$ 0.0001) was observed (Mokaya et al., 2020), with SBH having the highest values. The presence of these compounds (phytochemicals) in honey is an indication of its good quality (Ranneh et al., 2018), as they have been associated with most of the biofunctional properties of honey such as immune-stimulation, antimicrobial, anticancer, antiinflammatory, and antioxidant (Cianciosi et al., 2018). This was true even in the current study, as evidenced by the strong positive correlations between the antiradical activity (RSA) vs phenols $\left(r^{2}=0.754\right)$ and RSA vs flavonoids $\left(r^{2}=0.674\right)$, as shown in Fig. 3 . It is important to note that not only the quantity, but also the quality of the phytochemicals is responsible for the abovementioned biofunctional properties.

\subsection{Radical scavenging activity (RSA)}

The in-vitro radical scavenging activity ranged from 30.0 to $76.2 \%$ (Fig. 1, C), which was comparable to the findings reported for Malaysian SBH ( $90 \%$ for $40 \mathrm{mg} / \mathrm{ml}$ honey concentration) by Ranneh et al. (2018). Honeys from Liotrigona sp. exhibited the highest scavenging activity, with all its samples exhibiting $>50 \%$ scavenging ability (Fig. S1), while M. togoensis samples had the least activity. A study by Sousa et al. (2016) recorded a low range of 11.2 to $46.9 \%$, despite having used a higher concentration $(100 \mathrm{mg} / \mathrm{ml})$ than the one used in the present study (50 $\mathrm{mg} / \mathrm{ml}$ ). The antiradical activity was greatly influenced by the phenols and flavonoids (Fig. 3). Free radicals have been found to cause damage to biomolecules like DNA, RNA, proteins, and cell membranes, which eventually may lead to the development of diseases including cardiovascular dysfunctions and cancer (Cianciosi et al., 2018). Therefore, exogenous intake of antiradical molecules through the diet is vital to help counteract the damaging effects of free radicals (Cianciosi et al., 2018).

\section{Conclusions}

This study demonstrated that the bee species identity was a significant driver of the compositional profiles of SBH, with significant impacts on the physicochemical profile, phytochemical contents, and antiradical activity. On the other hand, there were no significant differences in honey composition between samples obtained through "punching holes" and "squeezing" harvesting methods. However, we support the use of "punching holes" as opposed to "squeezing", because with the latter method, solid debris are introduced in honey, and the pots are destroyed leaving the bees with a difficult task of rebuilding new pots.

Our results further showed that most of the studied samples were rich in phytochemicals (phenols and flavonoids) and exhibited significant radical scavenging activities, especially, Liotrigona sp. samples. We as well noted that moisture, free acidity, invertase, electrical conductivity, and HMF, in some of the studied SBH samples, failed to comply with the set standards for AMH. Therefore, we concur with those who have proposed the need to establish separate standards for SBH. We are confident that more coordinated research is required in this field with large-scale, structured surveys comparing stingless bee honeys to Apis mellifera honeys in sub-Saharan Africa and beyond.

\section{CRediT authorship contribution statement}

Hosea O. Mokaya: Conceptualization, Methodology, Investigation, Formal analysis, Writing - original draft. Kiatoko Nkoba: Conceptualization, Writing - review \& editing, Supervision, Funding acquisition. Robert M. Ndunda: Investigation, Formal analysis, Writing - review \& editing. Nicolas J. Vereecken: Writing - review \& editing, Supervision, Funding acquisition.

\section{Declaration of Competing Interest}

The authors declare that they have no known competing financial interests or personal relationships that could have appeared to influence the work reported in this paper.

\section{Acknowledgements}

The authors acknowledge NORAD for the generous financial support that facilitated filed sampling and laboratory analysis of honey samples. Our acknowledgments also go to F.R.S.-FNRS (Belgium) for the generous financial support to NJV via a "Projet de Recherches" (PDR project T.0255.20) entitled "Ecology of Afrotropical Stingless Bees". We also acknowledge icipe and the Government of Kenya for all facilitation provided for the accomplishment of this research. The authors gratefully acknowledge the financial support for this research by the following organisations and agencies: The European Union (DCI-FOOD/2013/ 313-659); the UK's Department for International Development (DFID); the Swedish International Development Cooperation Agency (SIDA, htt ps://www.sida.se/en); the Swiss Agency for Development and Cooperation (SDC); the Federal Democratic Republic of Ethiopia; and the Kenyan Government. The views expressed herein do not necessarily reflect the official opinion of the donors.

\section{Appendix A. Supplementary data}

Supplementary data to this article can be found online at https://doi. org/10.1016/j.foodchem.2021.130597.

\section{References}

AOAC. Association of Official Analytical Chemist, Official Methods of Analysis (2005). In: W. Horwitz (18. ed.). Gaithersburg, Maryland 20877-2417, USA.

Biluca, F. C., Braghini, F., Gonzaga, L. V., Costa, A. C. O., \& Fett, R. (2016). Physicochemical profiles, minerals and bioactive compounds of stingless bee honey (Meliponinae). Journal of Food Composition and Analysis, 50, 61-69. https://doi.org/ 10.1016/j.jfca.2016.05.007.

Biluca, F. C., Della Betta, F., De Oliveira, G. P., Pereira, L. M., Gonzaga, L. V., Costa, A. C. O., \& Fett, R. (2014). 5-HMF and carbohydrates content in stingless bee honey by CE before and after thermal treatment. Food Chemistry, 159, 244-249. https://doi.org/10.1016/j.foodchem.2014.03.016.

Chuttong, B., Chanbang, Y., Sringarm, K., \& Burgett, M. (2016). Physicochemical profiles of stingless bee (Apidae: Meliponini) honey from South East Asia (Thailand). Food Chemistry, 192, 149-155. https://doi.org/10.1016/j.foodchem.2015.06.089.

Cianciosi, D., Forbes-Hernández, T., Afrin, S., Gasparrini, M., Reboredo-Rodriguez, P., Manna, P., ... Battino, M. (2018). Phenolic compounds in honey and their associated health benefits: A review. Molecules, 23(9), 2322. https://doi.org/10.3390/ molecules 23092322 . 
Codex Alimentarius Commission. (2001). Codex standard for honey, CODEX STAN 121981. Codex Alimentarius Commission FAO/OMS.

Eardley, C., \& Kwapong, P. (2013). Taxonomy as a tool for conservation of African stingless bees and their honey. In Pot-Honey (pp. 261-268). New York, NY: Springer New York. https://doi.org/10.1007/978-1-4614-4960-7 18.

Espinoza Toledo, C., Vázquez Ovando, A., Torres de los Santos, R., López García, A., Albores Flores, V., \& Grajales-Conesa, J. (2018). Stingless bee honeys from Soconusco, Chiapas: A complementary approach. Revista de Biología Tropical, 66(4). https://doi.org/10.15517/rbt.v66i4.32181.

Fletcher, M. T., Hungerford, N. L., Webber, D., Carpinelli de Jesus, M., Zhang, J., Stone, I. S. J., ... Zawawi, N. (2020). Stingless bee honey, a novel source of trehalulose: A biologically active disaccharide with health benefits. Scientific Reports, 10(1), 12128. https://doi.org/10.1038/s41598-020-68940-0.

Gela, A., Hora, Z. A., Kebebe, D., \& Gebresilassie, A. (2021). Physico-chemical characteristics of honey produced by stingless bees (Meliponula beccarii) from West Showa zone of Oromia Region. Ethiopia. Heliyon, 7(1), e05875. https://doi.org/ 10.1016/j.heliyon.2020.e05875.

Gonzalez, V. H., Amith, J. D., \& Stein, T. J. (2018). Nesting ecology and the cultural importance of stingless bees to speakers of Yoloxóchitl Mixtec, an endangered language in Guerrero, Mexico. Apidologie, 49(5), 625-636. https://doi.org/10.1007/ s13592-018-0590-2.

Grüter, Christoph (University of Bristol UK, S. of B. S. (2020). Stingless Bees: Their behavior, ecology and evolution (eBook). Springer New York (Chapter 2). https:// doi.org/10/1007/978-3-030-60090-7.

Heard, T. A. (1999). The role of stingless bees in crop pollination. Annual Review of Entomology, 44(1), 183-206. https://doi.org/10.1146/annurev.ento.44.1.183.

Hempattarasuwan, P., Settachaimongkon, S., \& Duangmal, K. (2019). Impact of botanical source and processing conditions on physicochemical properties and antioxidant activity of honey in the northern part of Thailand. International Journal of Food Science \& Technology, 54(12), 3185-3195. https://doi.org/10.1111/ijfs. v54.1210.1111/ijfs.14253.

Holanda, C. A., Oliveira, A. R., Costa, M. C. P., Ribeiro, M. N.d. S., Souza, J. L., \& Araújo, M. J. A. M. (2012). Qualidade dos méis produzidos por Melipona fasciculata Smith da região do cerrado maranhense. Química Nova, 35(1), 55-58. https://doi. org/10.1590/S0100-40422012000100011.

International Honey Commission (ICH). (2009). Harmonised Methods of the International Honey Commission. Bee Product Science,. DOI:10.1007/s13398-014 0173-7.2.

Julika, W. N., Ajit, A., Ismail, N., Aqilah, N., Naila, A., \& Sulaiman, A. Z. (2020). Sugar profile and enzymatic analysis of stingless bee honey collected from local market in Malaysia. IOP Conference Series: Materials Science and Engineering, 736, Article 062001. https://doi.org/10.1088/1757-899X/736/6/062001.

Kassambara, A., \& Mundt, F. (2019). Factoextra: Extract and visualize the results of multivariate data analyses R package version 1.0. 5.999. http://www.sthda.com/ english/rpkgs/factoextra.

Lage, L. G. A., Coelho, L. L., Resende, H. C., Tavares, M. G., Campos, L. A. O., \& Fernandes-Salomão, T. M. (2012). Honey physicochemical properties of three species of the brazilian Melipona. Anais Da Academia Brasileira de Ciencias, 84(3), 605-608. https://doi.org/10.1590/S0001-37652012005000051.

Leonhardt, S. D., Heard, T. A., \& Wallace, H. (2014). Differences in the resource intake of two sympatric Australian stingless bee species. Apidologie, 45(4), 514-527. https:// doi.org/10.1007/s13592-013-0266-x.

Machado De-Melo, A. A., Almeida-Muradian, L. B.d., Sancho, M. T., \& Pascual-Maté, A. (2018). Composition and properties of Apis mellifera honey: A review. Journal of Apicultural Research, 57(1), 5-37. https://doi.org/10.1080/ 00218839.2017.1338444.

Moguel, L. K., Sosa-Moguel, O., Pino, J. A., Bolivar-Moreno, D., \& Cuevas-Glory, L. (2019). Physicochemical parametef liquid and spray-dried honey of stingless bee Scaptotrigona pectoralis. Journal of Apicultural Research, 1-9. https://doi.org/ 10.1080/00218839.2019.1688509.

Mokaya, H. O., Bargul, J. L., Irungu, J. W., \& Lattorff, H. M. G. (2020). Bioactive constituents, in vitro radical scavenging and antibacterial activities of selected Apis mellifera honey from Kenya. International Journal of Food Science \& Technology, 55(3), 1246-1254. https://doi.org/10.1111/ijfs.14403.
Nascimento, A., Marchini, L., Carvalho, C., Araújo, D., Olinda, R., \& Silveira, T. (2015). Physical-chemical parameters of honey of stingless bee (Hymenoptera: Apidae). American Chemical Science Journal, 7(3), 139-149. https://doi.org/10.9734/acsj/ 2015/17547.

Ndungu, N. N., Kiatoko, N., Ciosi, M., Salifu, D., Nyansera, D., Masiga, D., \& Raina, S. K. (2017). Identification of stingless bees (Hymenoptera: Apidae) in Kenya using morphometrics and DNA barcoding. Journal of Apicultural Research, 56(4), 341-353. https://doi.org/10.1080/00218839.2017.1327939.

Nkoba, K., Raina, S. K., Muli, E., Mithöfer, K., \& Mueke, J. (2012). Species richness and nest dispersion of some tropical meliponine bees (Apidae: Meliponinae) in six habitat types in the Kakamega forest, western Kenya. International Journal of Tropical Insect Science, 32(04), 194-202. https://doi.org/10.1017/S1742758412000355.

Nordin, A., Sainik, N. Q. A. V., Chowdhury, S. R., Saim, A. B., \& Idrus, R. B. H. (2018). Physicochemical properties of stingless bee honey from around the globe: A comprehensive review. Journal of Food Composition and Analysis, 73, 91-102. https://doi.org/10.1016/j.jfca.2018.06.002.

Oddo, L. P., Heard, T. A., Rodríguez-Malaver, A., Pérez, R. A., Fernández-Muiño, M., Sancho, M. T., ... Vit, P. (2008). Composition and antioxidant activity of Trigona carbonaria honey from Australia. Journal of Medicinal Food, 11(4), 789-794. https:// doi.org/10.1089/jmf.2007.0724.

Perichon, S., Heard, T. A., \& Schouten, C. (2020). Perceptions of keepers of stingless bees (Tetragonula, Austroplebeia) regarding Aboriginal beliefs and practices in Australia. Journal of Apicultural Research, 59, 1-13. https://doi.org/10.1080/ 00218839.2020.1842590.

R Core Team (2018) R: A language and environment for statistical computing. $\mathrm{R}$ foundation for statistical computing, Vienna, Austria. https://www.R-project.org.

Ranneh, Y., Ali, F., Zarei, M., Akim, A. M., Hamid, H. A., \& Khazaai, H. (2018). Malaysian stingless bee and Tualang honeys: A comparative characterization of total antioxidant capacity and phenolic profile using liquid chromatography-mass spectrometry. LWT, 89, 1-9. https://doi.org/10.1016/j.lwt.2017.10.020.

Rao, P. V., Krishnan, K. T., Salleh, N., \& Gan, S. H. (2016). Biological and therapeutic effects of honey produced by honey bees and stingless bees: A comparative review. Revista Brasileira de Farmacognosia, 26(5), 657-664. https://doi.org/10.1016/j. bjp.2016.01.012.

RStudio Team. (2016). RStudio: Integrated development environment for R. Boston, MA. http://www.rstudio.com/.

Schloerke, B., Crowley, J., Cook, D., Briatte, F., Marbach, M., Thoen, E., ... \& Larmarange, J. (2018). Ggally: Extension to ggplot2. R package version, 1(0). http://CRAN.R-project.org/package=GGally.

Shamsudin, S., Selamat, J., Sanny, M., Abd. Razak, S.-B., Jambari, N. N., Mian, Z., \& Khatib, A. (2019). Influence of origins and bee species on physicochemical, antioxidant properties and botanical discrimination of stingless bee honey. International Journal of Food Properties, 22(1), 239-264. https://doi.org/10.1080/ 10942912.2019.1576730.

Shapla, U. M., Solayman, M., Alam, N., Khalil, M. I., \& Gan, S. H. (2018). 5Hydroxymethylfurfural (HMF) levels in honey and other food products: Effects on bees and human health. Chemistry Central Journal, 12(1), 35. https://doi.org/ 10.1186/s13065-018-0408-3.

Sousa, J. M. B.d., Souza, E. L.d., Marques, G., Benassi, M.d. T., Gullón, B., Pintado, M. M., \& Magnani, M. (2016). Sugar profile, physicochemical and sensory aspects of monofloral honeys produced by different stingless bee species in Brazilian semi-arid region. LWT - Food Science and Technology, 65, 645-651. https://doi.org/10.1016/j. lwt.2015.08.058.

Wickham, H., Chang, W., \& Wickham, M. H. (2016). Package 'ggplot2'. Create elegant data visualisations using the grammar of graphics. Version, 2(1), 1-189. https://cr an.r-project.org/web/packages/ggplot2/ggplot2.pdf.

Yap, S. K., Chin, N. L., Yusof, Y. A., \& Chong, K. Y. (2019). Quality characteristics of dehydrated raw Kelulut honey. International Journal of Food Properties, 22(1), 556-571. https://doi.org/10.1080/10942912.2019.1590398.

Zimmerman, D. A. (1972). The avifauna of the Kakamega Forest, western Kenya, including a abird population study. Bulletin of the American Museum of Natural History, 44(8), 08520. https://doi.org/10.1007/s13398-014-0173-7.2. 